\title{
Az ökológiai és a konvencionális joghurtfogyasztás lehetséges szerepe a nem alkoholos zsírmájbetegség kezelésében
}

\author{
Egresi Anna dr. ${ }^{1}$ - Drexler Dóra dr. ${ }^{2}$ - Hagymási Krisztina dr. ${ }^{1}$ \\ Blázovics Anna dr. ${ }^{3}$. Jakab Zsuzsanna dr. ${ }^{1}$. Kocsis Ibolya dr. ${ }^{4}$ \\ Dakó Sarolta $^{1}$. Bacsárdi Anna oh. ${ }^{1}$. Lengyel Gabriella dr. ${ }^{1}$
}

\author{
${ }^{1}$ Semmelweis Egyetem, Általános Orvostudományi Kar, Belgyógyászati és Hematológiai Klinika, Budapest \\ ${ }^{2}$ Ökológiai és Mezőgazdasági Kutatóintézet, Budapest \\ ${ }^{3}$ Semmelweis Egyetem, Gyógyszerésztudományi Kar, Farmakognóziai Intézet, Budapest \\ ${ }^{4}$ Semmelweis Egyetem, Központi Laboratórium, Budapest
}

\begin{abstract}
Bevezetés: Napjainkban az egészséges életmódra törekvés fontos ösztönző tényező mind a bio-, mind a funkcionális élelmiszerek fogyasztására. A bioélelmiszerek kevesebb növényvédőszer-maradékot és szignifikánsan több, egészségre kedvező vegyületeket tartalmaznak, mint például a növényi termékek polifenoljait, valamint a tejben és a húskészítményekben található, többszörösen telítetlen zsírsavakat. A legújabb tanulmányok szerint a bél-máj tengely fontos szerepet játszik a nem alkoholos zsírmájbetegség (NAFLD) patogenezisében, így a pre- és probiotikumok terápiás eszközök lehetnek. Az ökológiai gazdálkodásból származó joghurtok egészségre gyakorolt hatásait az úgynevezett hagyományos joghurtokkal azért nehéz összehasonlítani, mert nincs kellően érzékeny biomarker.

Célkitüzés: Munkánk során azt vizsgáltuk, hogy különböző biomarkerek mennyire használhatók annak kimutatására, hogy hogyan hat a hagyományos és az ökológiai joghurt a NAFLD-ben szenvedő betegek állapotára.

Betegek és módszer: Prospektív, kohorszos vizsgálatot végeztünk 37 (életkor $=51,73 \pm 11,82$, férfi $=21$, nő $=16$ ), nem alkoholos zsírmájbetegségben szenvedő beteg bevonásával. A NAFLD diagnosztizálása ultrahangvizsgálaton és egyéb etiológia kizárásán alapult. A betegeket shear wave elasztográfiával is megvizsgáltuk a májfibrosis stádiumának meghatározására. A betegeket véletlenszerúen két csoportra osztottuk. A betegek egyenként 8 héten keresztül napi 300 gramm ökológiai $(\mathrm{n}=21)$ vagy hagyományos $(\mathrm{n}=16)$ gazdálkodásból származó joghurtot fogyasztottak. 37 rutin laboratóriumi adatot vizsgáltunk, mértünk 4 citokinkoncentrációt, 3 redoxhomeosztázis-markert és 14 testösszetétel-értéket a joghurtok fogyasztása előtt, befejezéskor, valamint 12 héttel a befejezés után.

Eredmények: Mindkét joghurt fogyasztását követően enyhén növekedett a D-vitamin-szint, és minimálisan csökkent a LDL-szint, a többi 35 rutin laboratóriumi adatban statisztikailag nem volt különbség. Az adiponektin $(8793,64 \pm$ $5365,98 \mathrm{pg} / \mathrm{ml}-13161,33 \pm 8346,24 \mathrm{pg} / \mathrm{ml})$ és a leptin $(161,70 \pm 158,41-277,94 \pm 188,15 \mathrm{pg} / \mathrm{ml})$ szintje megemelkedett a 8 hetes joghurtfogyasztás után a „hagyományos csoportban”. Ezzel szemben a kezelés után az adiponektinszintek szignifikáns csökkenését tapasztaltuk az „ökológiai csoportban” (12 017,57143 \pm 7122,12 $8833,5 \pm 5216,17)$. A két csoportban csak az adiponektin tendenciája különbözött. Az indukált szabad gyökök mennyisége statisztikailag szintén alacsonyabb $(10,05 \pm 16,67-5,58 \pm 4,41)$ volt közvetlenül a joghurtok fogyasztása után. A testösszetétel-mérés eredményei (testsúly, teljes testvíz, fehérje, ásványi anyagok, testzsírtömeg, vázizomtömeg, testtömegindex, testzsírszázalék, visceralis zsír területe, alapanyagcsere, derék-csípő arány, a csontok ásványianyag-tartalma, testsejttömeg) között nem volt szignifikáns különbség.

Következtetés: Ezek az adatok arra utalnak, hogy az adiponektin lehetséges biomarkerként szerepelhet a nem alkoholos zsírmájbetegségben alkalmazott probiotikus kezelés hatékonyságának értékeléséhez. Munkánk az alapját képezheti a jövőbeli tanulmányoknak, amelyek a (bio)joghurt fogyasztása és az egészségre gyakorolt hatások közötti összefüggéseket vizsgálják.
\end{abstract}

Orv Hetil. 2020; 161(35): 1466-1474.

Kulcsszavak: bél-máj tengely, ökológiai joghurt, adiponektin, leptin 


\section{The potential role of organic and conventional yoghurt consumption in the treatment of non-alcoholic fatty liver disease}

Introduction: Health is an important motivation for the consumption of both organic and functional foods. Organic food contains fewer pesticide residues and statistically more selected health-related compounds such as polyphenols in plant products and polyunsaturated fatty acids in milk and meat products. Recent studies suggest that the gutliver axis plays an important role in the pathogenesis of non-alcoholic fatty liver disease, so probiotics could be a therapeutic tool. Comparing the health effects of yoghurt from organic origin with so-called conventional yoghurt is difficult, because there is no biomarker that would signal the difference with good specificity and sensitivity.

Aim: The aim of this study was to investigate numerous biomarkers to evaluate the difference between yoghurt from conventional and organic origin and their health effects in NAFLD.

Patients and method: We performed a prospective, cohort study consisting of 37 (age $=51.73 \pm 11.82$, male $=21$, female = 16) patients with NAFLD at the 2nd Department of Internal Medicine of the Semmelweis University, Budapest. Diagnosis of NAFLD was based on ultrasonography and the exclusion of other etiololgy. The patients were examined also with shear wave elastography to evaluate the hepatic fibrosis stage. We divided the patients randomly into two groups. The patients consumed individually daily 300 grams of yoghurt from organic $(n=21)$ or conventional $(n=16)$ origin for 8 weeks. We collected 37 routine laboratory data, measured 4 cytokines, 3 markers of the redox-homeostasis and 14 body composition values before, after, and 12 weeks after the yoghurt consumption. Results: We found a mild elevation of vitamin D and a minimal reduction of LDL after the yoghurt consumption, but in the other 35 routine laboratory data there was no statistical difference. Adiponectin and leptin levels were elevated after the yoghurt consumption in the "conventional group". In contrast, we found significant decrease of adiponectin levels in the "organic group" after the treatment. Only the adiponectin tendency was different in the two groups. The induced free radical content was also statistically lower after the yoghurt consumption. In the body composition measurements, there were no significant differences.

Conclusion: These data suggest that adiponectin could be a possible biomarker to evaluate the effectiveness of probiotic treatment in non-alcoholic fatty liver disease. Our work can serve as a basis for future studies investigating relationships between organic yoghurt consumption and health outcomes.

Keywords: gut-liver axis, organic yoghurt, adiponectin, leptin

Egresi A, Drexler D, Hagymási K, Blázovics A, Jakab Zs, Kocsis I, Dakó S, Bacsárdi A, Lengyel G. [The potential role of organic and conventional yoghurt consumption in the treatment of non-alcoholic fatty liver disease]. Orv Hetil. 2020; 161(35): 1466-1474.

(Beérkezett: 2020. április 8.; elfogadva: 2020. április 16.)

\section{Rövidítések}

ALP = alkalikus foszfatáz; ANOVA = (analysis of variance) varianciaanalízis; $\mathrm{DPPH}=(1,1$-diphenyl-2-picrylhydrazyl $)$ 1,1-difenil-2-pikrilhidrazil; GGT = gamma-glutamil-transzferáz; GOT = glutamát-oxálacetát-transzferáz; GPT = glutamátpiruvát-transzamináz; HDL $=($ high-density lipoprotein $)$ magas sürüségú lipoprotein; HDON = hidrogéndonor; IL6 = interleukin-6; INR = (international normalized ratio) nemzetközi normalizált ráta; IQR = (interquartile range) interkvartilis tartomány; $\mathrm{kPa}=$ kilopascal; $\mathrm{LDL}=$ (low-density lipoprotein $)$ alacsony sürúségü lipoprotein; LS = (liver stiffness) májtömöttség; $\mathrm{LSD}=$ (least significant difference) legkevesebb jelentős különbség; NAFLD = (non-alcoholic fatty liver disease $)$ nem alkoholos zsírmájbetegség; $\mathrm{PBC}=$ primer biliaris cholangitis; PSC = primer szklerotizáló cholangitis; RLU = (relative light unit) relatív fényegység; $\mathrm{TNF} \alpha=$ tumornekrózisfaktor-alfa; TUKEB = Tudományos és Kutatásetikai Bizottság

A nem alkoholos zsírmájbetegség (NAFLD) komoly egészségügyi terhet jelent világszerte. Kihívásként jelentkezik a klinikusok számára a diagnosztika és a kezelés szempontjából egyaránt. Emiatt a hepatológia ezen terü- letének számos kutatója próbálja megérteni a patogenezist. A klinikai kutatások a közelmúltban a bél-máj tengely szerepére irányultak. A terápiás és megelőző stratégiáknál a bélflóra befolyásolása ideális választásnak tûnik. A NAFLD egyik fontos szerzett kockázati tényezője a táplálkozás. Tanulmányok igazolják, hogy a NAFLD fó táplálkozási kockázati tényezőit az ómega-3 és ómega-6 zsírsavak egyensúlyának felborulása, valamint a túlzott fruktóz- és telítettzsírsav-bevitel jelenti [1].

A tápanyagok felszívódásának és az anyagcserének a legfontosabb szervei a bél és a máj, amelyek szorosan kapcsolódnak egymáshoz a portalis keringésen keresztül. A bélból felszívódó különféle anyagok (például epesavak, tápanyagok, gyógyszerek, exogén és endogén toxinok) belépnek az enterohepaticus körforgásba, így befolyásolva mindkét szerv múködését $[2,3]$.

Másodlagos tüzfalként a máj védi a szervezetet a bélbe belépő kórokozók és az általuk előállított endotoxinok (lipopoliszacharidok) ellen. Az endotoxinok fontos szerepet játszanak a májbetegségek és számos különböző, szisztémás betegség patogenezisében is. A baktériumok és ezek termékei aktiválják a Kupffer-sejteket és a májne- 
utrofileket. A gyulladásos citokinek és kemokinek termelése gyulladásos sejteket toborozhat, amelyek a májszövet kötőszövetes átalakulásához vezethetnek [4].

Ezenkívül a máj a bélfunkciókat is szabályozza. A máj microsomáiban előállított epesavak fontos szerepet játszanak a lipidek és a lipidben oldódó vitaminok felszívódásában, valamint a bélben lévô endotoxinok méregtelenítésében. Az epesavak hatására az endotoxinok nem szívódnak fel a bél nyálkahártyáján $[5,6]$.

E két szerv kétirányú kommunikációja miatt a bél mikrobiomjának fontosságát a NAFLD terápiájában széles körben vizsgálják. A különböző étrendek megváltoztathatják a bélflóra összetételét. A fermentált élelmiszerek számos kultúrában az étrend részévé váltak, és az utóbbi időben kiderült, hogy az erjesztés számos egészségügyi elónnyel jár. Emiatt a fermentált termékek a közelmúltban felkeltették a tudományos érdeklődést. A folyamatban részt vevő mikroorganizmusokat, elsősorban a tejsavbaktériumokat, a közelmúltban számos egészségügyi előnnyel társították. A fermentáció során ezek a baktériumok vitaminokat, ásványi, prebiotikus (exopoliszacharidok), antimikrobiális (bakteriocinek, szfingolipidek) anyagokat szintetizálnak, valamint biológiailag aktív zsírsavakat (konjugált linolsavak) állítanak elő. Ennek eredményeként a fermentált élelmiszerek antioxidáns, antidiabetikus, antikarcinogén, antiatheroscleroticus, antimikrobiális, gombaellenes és gyulladásgátló hatásúak [7]. A legújabb tanulmányok azt mutatják, hogy a probiotikus fermentált élelmiszerek csökkenthetik a kóros májenzimeltéréseket, az alacsony denzitású lipoprotein, a koleszterin szintjét és a testtömeget $[2,8-10]$, amely hatások kedvezően befolyásolják a zsírmájbetegség lefolyását.

Az ökológiai gazdálkodásból származó tejtermékeknek a probiotikumok hordozójaként történő felhasználása további előnyökkel járhat. A biotej ugyanis általában a tavaszi és nyári hónapokban legeltetett tehenektől származik. Az így nyert tejet vegyi kezelésektől mentesen dolgozzák fel és csomagolják [11]. Az ökológiai gazdálkodásból származó tej kedvezőbb zsírsavprofillal rendelkezik, így következetesen több bioaktív zsírsavat (rövid szénláncú, páratlan és elágazó szénláncú zsírsav, vakcensav és konjugált linolsav) tartalmaz adagonként, különösen a nyári hónapokban [12]. További előnyt jelent, hogy a jelenleg használt antibiotikumok és növényvédó szerek nem mutathatók ki a biogazdálkodásból származó tejtermékekben, míg a konvencionálisan eloállított tejmintákban akár szintetikus növekedésihormon-maradványok is előfordulhatnak [13]. A tejtermékekkel és a táplálkozással kapcsolatos új kutatások segítik ezen élelmiszerek, a bennük található bioaktív vegyületek és az emberi testre gyakorolt hatásuk közötti összefüggések jobb megértését [10].

Munkánk során célunk volt az ökológiai gazdálkodásból származó joghurtfogyasztás összehasonlítása a hagyományosan elóállított joghurtokkal a NAFLD-ben szenvedő betegek klinikai paramétereinek monitorizálásával és speciális biomarkerek meghatározásával.

\section{Anyagok és módszer}

\section{Betegek}

Vizsgálatunkba 37 (életkor $=51,73 \pm 11,82$, férfi $=21$, nő = 16) NAFLD-ben szenvedő beteget vontunk be, tájékozott beleegyezést követően. Mind a 37 betegnél kóros májenzimszinteket mértünk, ultrahangvizsgálattal zsírmáj ábrázolódott, és hepatológiai gondozás alatt álltak.

Az összes egyéb lehetséges etiológiát - mint például vírushepatitis, autoimmun hepatitis, PSC, PBC, Wilsonkór, haemochromatosis és gyógyszerindukált májbetegség - kizártuk. Ezen betegek egyikénél sem volt alkoholabúzus a kórtörténetben, és egyikük sem fogyasztott napi $20 \mathrm{~g}$-nál több alkoholt. A betegek egyikében sem volt jól definiált örökletes szindrómára vonatkozóan pozitív családi anamnézis. A társbetegségek közül a betegek 46\%-a hypertoniában, 8\%-a 2-es típusú diabetes mellitusban, 17\%-a dyslipidaemiában szenvedett. A betegek gyógyszerelését az 1. táblázatban foglaltuk össze.

A Semmelweis Egyetem Tudományos és Kutatási Regionális és Intézményi Bizottsága jóváhagyta a Helsinki Nyilatkozat szerint elvégzett tanulmányt. A TUKEB-engedély száma: 145/2016.

\section{A kutatás menete}

A betegeket véletlenszerúen két csoportra osztottuk. Az első csoport $(\mathrm{n}=21$ fó) ökológiai eredetû́ joghurtot, a második csoport hagyományos joghurtot $(\mathrm{n}=16$ fó) fogyasztott. A joghurtok összetételét a 2. táblázat tartalmazza. A vizsgálat során mindkét csoport tagjai naponta $300 \mathrm{~g}$ joghurtot fogyasztottak 8 héten keresztül. A betegek a joghurt minőségének fenntartása érdekében a termékeket hútőszekrényben $\left(+4^{\circ} \mathrm{C}\right)$ tárolták. A joghurtokat eredeti formájukban fogyasztották, valamilyen ízesítószerrel (só, cukor, gyümölcs, lekvár, magvak stb.) történő dúsítása nem volt engedélyezve. A betegek a továbbiakban életmódjukon, étkezési szokásaikon, valamint gyógyszerelésükön nem változtattak.

1. táblázat |A résztvevók tartósan szedett gyógyszerei

\begin{tabular}{lcc}
\hline & $\begin{array}{c}\text { Biojoghurtot } \\
\text { fogyasztók } \\
(\mathrm{n}=21 \text { fó }) \\
(\text { fó) }\end{array}$ & $\begin{array}{c}\text { Konvencionális } \\
\text { joghurtot } \\
\text { fogyasztók } \\
(\mathrm{n}=16 \text { fó }) \\
(\text { fó })\end{array}$ \\
\hline Antihipertenzívum & 6 & 9 \\
Máriatövis-tartalmú készítmény & 4 & 2 \\
Oralis antidiabetikum & 1 & 2 \\
Urzodezoxikólsav-tartalmú & 2 & 1 \\
készítmény & 0 & 1 \\
C-vitamin & 0 & 3 \\
D-vitamin & & \\
\hline
\end{tabular}


2. táblázat |A joghurtok összetétele

\begin{tabular}{|c|c|c|}
\hline & $\begin{array}{c}\text { Konvencionális } \\
\text { joghurt }\end{array}$ & Biojoghurt \\
\hline & $100 \mathrm{~g}$ & $100 \mathrm{~g}$ \\
\hline Energia & $273 \mathrm{~kJ} / 65 \mathrm{kcal}$ & $285 \mathrm{~kJ} / 68 \mathrm{kcal}$ \\
\hline Szénhidrát (g) & 4,8 & 4,2 \\
\hline Fehérje (g) & 3,4 & 4,2 \\
\hline Só (g) & 0,1 & 0,13 \\
\hline Zsír (g) & 3,6 & 3,6 \\
\hline $\begin{array}{l}\text { amelyből telített zsírsavak } \\
\text { (g) }\end{array}$ & 2,4 & 2,5 \\
\hline $\begin{array}{l}\text { l× telítetlen zsírsavak } \\
(\text { MUFA })(\mathrm{g})\end{array}$ & 0,97 & 1,04 \\
\hline $\begin{array}{l}\text { többszörösen telítetlen } \\
\text { zsírsavak (PUFA) (g) }\end{array}$ & 0,16 & 0,15 \\
\hline Kolekalciferol $(\mu \mathrm{g} / \mathrm{kg})$ & $<12,5$ & $<12,5$ \\
\hline dl-Alfa-tokoferol $(\mathrm{mg} / \mathrm{kg})$ & $<5$ & $<5$ \\
\hline Foszfor (g) & 0,093 & 0,115 \\
\hline Kalcium (g) & 0,117 & 0,154 \\
\hline Magnézium (g) & 0,01 & 0,012 \\
\hline Szelén (mg/kg) & $<0,03$ & $<0,03$ \\
\hline Réz $(\mathrm{mg} / \mathrm{kg})$ & $<0,03$ & $<0,03$ \\
\hline Vas $(\mathrm{mg} / \mathrm{kg})$ & 0,14 & 0,33 \\
\hline Mangán $(\mathrm{mg} / \mathrm{kg})$ & $<0,03$ & $<0,03$ \\
\hline Cink $(\mathrm{mg} / \mathrm{kg})$ & 0,34 & 0,85 \\
\hline $\begin{array}{l}\text { Baktériumszám (Streptococcus } \\
\text { thermophilus, Lactobacillus } \\
\text { bulgaricus) }\end{array}$ & $3,0 \times 10 \mathrm{E}^{8}$ & $2,4 \times 10 \mathrm{E}^{8}$ \\
\hline
\end{tabular}

MUFA = egyszeresen telítetlen zsírsavak; PUFA = többszörösen telítetlen zsírsavak

A résztvevők vénás vérvétele háromszor történt a vizsgálat időtartama alatt (a joghurt fogyasztása előtt, után és 12 héttel a befejezést követően).

\section{Rutin laboratóriumi paraméterek}

A szokásos kémiai vizsgálatokat vénás vérmintából végezték a Semmelweis Egyetem Központi Laboratóriumában. A következő paramétereket mértük és analizátorokat alkalmaztuk: teljes vérkép, vércukorszint, összkoleszterin, HDL- és LDL-koleszterin, triglicerid, összes bilirubin, direkt bilirubin, albumin, összfehérje, GGT, GOT, GPT, alkalikus foszfatáz (ALP), kreatinin, karbamid, húgysav, kálium, nátrium, foszfor, kalcium, vas, transzferrin, ferritin, cink, réz, protrombin, INR, D-vitamin; Sysmex XN-1000 hematológiai analizátor, AU5800 kémiai analizátor (Beckman Coulter, Brea, CA, USA), Innovin, Dade (R) BCS XP analizátor (Siemens, München, Németország), LIAISON XL automata analizátor (DiaSorin, Saluggia, Olaszország).

\section{Vérminták elökészitése a speciális elemzésekhez}

A vérmintákat 3,2\%-os nátrium-citrát oldatos Vacuette ${ }^{\circledR}$ csövekben (Greiner Bio-One, Kremsmünster, Ausztria) vettük. A vérvétel után a mintákat $4{ }^{\circ} \mathrm{C}$-on tároltuk, és ugyanazon a napon szeparáltuk. A vérplazmát elválasztottuk az erythrocyták frakciójától centrifugálással (2500 fordulat/perc sebességgel 10 percig), és a határréteget (buffy coat) eltávolítottuk. A vérszeparálás után a plazmát $-80{ }^{\circ} \mathrm{C}$-on tároltuk. A citokin- és a redoxparaméterméréseket 6 hónapon belül elvégeztük.

\section{Citokinszintmérések}

Négy citokin - a TNF $\alpha$, az IL6, a leptin és az adiponektin - plazmaszintjét enzimkapcsolt immunszorbens-vizsgálati (ELISA) kitekkel (Sigma-Aldrich, St. Louis, MO, USA) mértük a gyártó utasításai szerint. Az abszorbanciaszintet $450 \mathrm{~nm}$ hullámhosszon leolvastuk mikrolemez-olvasóval (Stat Fax 2000 Microplate Reader, Awareness Technology, Inc., Palm City, FL, USA), és az adatokat kiértékeltük.

\section{A redox-homeosztázis markerei}

A teljes gyökfogó kapacitást (indukált kemilumineszcenciás vizsgálat) Lumat 9501 luminométerrel (Berthold Technologies, Bad Wildbad, Németország) határoztuk meg a Blázovics és mtsai által kidolgozott módszer alapján [14]. A plazma kemilumineszcenciás intenzitását a standard fény relatív fényegységében (RLU\%) fejeztük ki.

A minták H-donor (HDON)-aktivitását Hatano módszerével [15] határoztuk meg 1,1-difenil-2-pikrilhidrazil (DPPH) stabil szabad gyök segítségével, spektrofotométerrel. A metanolos DPPH-festék abszorbanciáját 517 nm-en határoztuk meg. A tevékenység jellemzéséhez a gátlás\%-ot adtuk meg. Gátlás\% = [Abs (kontroll $)-($ Abs (minta) - Abs (minta DPPH nélkül)] / Abs (kontroll) $\times$ 100 .

A szabadszulfhidril-csoportok tartalmát Ellman és Lysko módszerével [16] határoztuk meg 5,5'-ditio-bisnitrobenzoesav reagenssel Na-foszfát pufferben $(\mathrm{pH}$ 7,4) 512 nm-en. Standardként redukált glutationt használtunk.

Az összes spektrofotometriás mérést U-2000 spektrofotométerrel (Hitachi, Tokió, Japán) végeztük.

\section{Shear wave elasztográfia}

A májfibrosis mértékét shear wave (szuperszonikus nyíráshullámmal múködő) elasztográfiás módszerrel határoztuk meg. A máj tömöttségét (LS) a rugalmasság medián értékeivel mértük Aplio 500 ultrahangkészülékkel (Toshiba, Tokió, Japán). Mindegyik betegnél 5 érvényes mérést végeztünk, amelyek után kiszámítottuk a medián értéket, és az eredményeket kPa-ban fejeztük ki. Ebben 


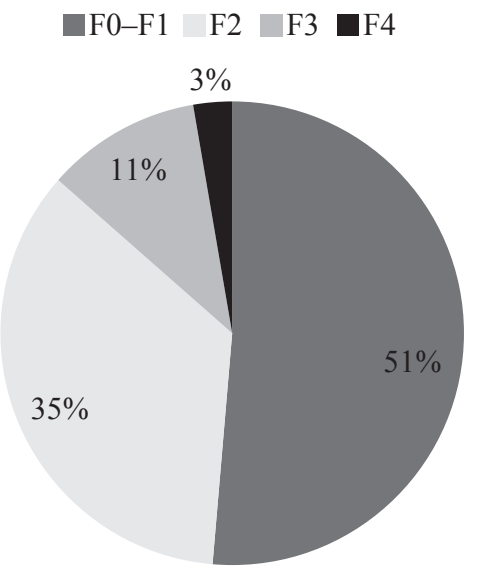

1. ábra

| A betegek megoszlása a fibrosisstádium szerint $(\mathrm{n}=37$ fó)

a tanulmányban csak azokat az LS-méréseket vettük figyelembe, amelyeknek interkvartilis tartománya (IQR) kevesebb, mint 30\%. A fibrosisstádiumok meghatározáshoz az alábbi 'cut-off' értékeket alkalmaztuk: F0-Fl: $<7 \mathrm{kPa}, \mathrm{F} 2$ : $>7 \mathrm{kPa}, \mathrm{F} 3:>9,5 \mathrm{kPa}, \mathrm{F} 4:>12 \mathrm{kPa}$. A betegek megoszlását a májfibrosis stádiuma szerint az 1 ábra foglalja össze.

\section{A test összetételének mérése}

A vizsgálat során a bioelektromos impedancia elvén alapuló módszer segítségével háromszor mértünk 14 testösszetétel-értékét (InBody, Cerritos, CA, USA).

\section{Statisztikai analizis}

A statisztikai elemzéshez egyirányú ANOVA- és LSD post-hoc teszteket végeztünk. A szignifikanciát $\mathrm{p}<0,05$ értéken határoztuk meg. Az elemzést Statistica 13.2 programmal (StatSoft, Inc., Tulsa, OK, USA) végeztük.

\section{Anyagok}

Az ökológiai joghurtokat a Kärntnermilchtől (Spittal/ Drau, Ausztria), a hagyományos joghurtokat a SoleMizo Zrt.-től (Szeged) szereztük be. TNF $\alpha$, IL6, leptin, adiponektin, DPPH, stabil gyök, hidrogén-peroxid, luminol, mikroperoxidáz: a Sigma-Aldrichtól (St. Louis, MO, USA) származnak. A standard oldatokat, salétromsavat és sósavat, valamint a fel nem sorolt, analitikai tisztaságú vegyületeket a Reanaltól (Budapest) vásároltuk.

3. táblázat | A laboratóriumi paraméterek változása a két csoportban (*szignifikancia $\mathrm{p}<0,05)$

\begin{tabular}{|c|c|c|c|c|c|c|c|c|}
\hline \multicolumn{3}{|c|}{ Laboratóriumi paraméterek } & \multicolumn{2}{|c|}{$\begin{array}{l}\text { Joghurtfogyasztás előtt } \\
\text { (átlag } \pm \text { szórás) }\end{array}$} & \multicolumn{2}{|c|}{$\begin{array}{l}\text { Joghurtfogyasztás után } \\
\text { (átlag } \pm \text { szórás) }\end{array}$} & \multicolumn{2}{|c|}{$\begin{array}{l}\text { Joghurtfogyasztás után } 12 \text { héttel } \\
\text { (átlag } \pm \text { szórás) }\end{array}$} \\
\hline & $\begin{array}{l}\text { Mérték- } \\
\text { egység }\end{array}$ & $\begin{array}{l}\text { Normál- } \\
\text { tartomány }\end{array}$ & $\begin{array}{l}\text { Biojoghurtot } \\
\text { fogyasztók } \\
(\mathrm{n}=21 \text { fó) }\end{array}$ & $\begin{array}{l}\text { Konvencionális } \\
\text { joghurtot } \\
\text { fogyasztók } \\
(\mathrm{n}=16 \text { fó) }\end{array}$ & $\begin{array}{l}\text { Biojoghurtot } \\
\text { fogyasztók } \\
(\mathrm{n}=21 \text { fö) }\end{array}$ & $\begin{array}{l}\text { Konvencionális } \\
\text { joghurtot } \\
\text { fogyasztók } \\
(\mathrm{n}=16 \text { fó })\end{array}$ & $\begin{array}{l}\text { Biojoghurtot } \\
\text { fogyasztók } \\
(\mathrm{n}=21 \text { fó })\end{array}$ & $\begin{array}{c}\text { Konvencionális } \\
\text { joghurtot } \\
\text { fogyasztók } \\
(\mathrm{n}=16 \text { fó) }\end{array}$ \\
\hline GOT & $\mathrm{U} / \mathrm{l}$ & $4-37$ & $34,33 \pm 13,94$ & $31,94 \pm 11,6$ & $38,6 \pm 16,88$ & $40,5 \pm 23,93$ & $33,16 \pm 11,41$ & $37,64 \pm 15,84$ \\
\hline GPT & $\mathrm{U} / 1$ & $4-40$ & $51 \pm 29,59$ & $43,43 \pm 19,98$ & $53,2 \pm 33,33$ & $62,75 \pm 51,47$ & $46,32 \pm 23,44$ & $54,5 \pm 24,61$ \\
\hline GGT & $\mathrm{U} / \mathrm{l}$ & $7-52$ & $108,48 \pm 121,23$ & $93,31 \pm 57,59$ & $114,7 \pm 170,35$ & $141,45 \pm 108,97$ & $123,47 \pm 221,31$ & $113,21 \pm 95,12$ \\
\hline ALP & $\mathrm{U} / 1$ & $100-290$ & $95 \pm 30,27$ & $110,06 \pm 47,85$ & $98,15 \pm 40,32$ & $126,5 \pm 72,33$ & $98,79 \pm 51,01$ & $114,29 \pm 54,96$ \\
\hline Összkoleszterin & $\mathrm{mmol} / \mathrm{l}$ & $3,9-5,6$ & $5,59 \pm 0,85$ & $5,68 \pm 1,17$ & $5,63 \pm 0,87$ & $5,77 \pm 1,31$ & $5,56 \pm 0,92$ & $5,67 \pm 1,05$ \\
\hline LDL & $\%$ & $44,2-54,7$ & $64,34 \pm 3,27$ & $64,71 \pm 4,68$ & $63,13 \pm 2,97$ & $64,06 \pm 3,1$ & $68,08 \pm 3,62$ & $67,65 \pm 2,81$ \\
\hline HDL & $\%$ & $23,4-38,2$ & $23,91 \pm 5,4$ & $25,97 \pm 5,6$ & $23,88 \pm 4,48$ & $23,1 \pm 4,35$ & $23,19 \pm 5,46$ & $21,03 \pm 4,49$ \\
\hline Trigliceridek & $\mathrm{mmol} / \mathrm{l}$ & $0,8-1,8$ & $1,86 \pm 0,73$ & $1,84 \pm 0,75$ & $1,61 \pm 0,67$ & $1,99 \pm 0,88$ & $1,66 \pm 0,68$ & $2,01 \pm 1,06$ \\
\hline Thrombocyta & $\mathrm{G} / 1$ & $150-450$ & $265,09 \pm 77,41$ & $268,75 \pm 64,47$ & $259,05 \pm 83,18$ & $268,94 \pm 73,74$ & $261,16 \pm 83,75$ & $262,57 \pm 65,35$ \\
\hline Protrombin & $\%$ & $70-100$ & $101,81 \pm 15,83$ & $102,07 \pm 16,65$ & $101,25 \pm 14,42$ & $99,6 \pm 29,39$ & $106,79 \pm 16,49$ & $104,67 \pm 17,22$ \\
\hline INR & & $0,98-1,3$ & $0,99 \pm 0,08$ & $1,01 \pm 0,09$ & $0,99 \pm 0,07$ & $0,98 \pm 0,1$ & $0,98 \pm 0,08$ & $0,99 \pm 0,09$ \\
\hline Glükóz & $\mathrm{mmol} / \mathrm{l}$ & $3,3-5,9$ & $5,59 \pm 1,41$ & $5,63 \pm 1,34$ & $5,92 \pm 1,37$ & $5,99 \pm 1,64$ & $5,83 \pm 1,15$ & $6,26 \pm 2,28$ \\
\hline Összfehérje & $\mathrm{g} / 1$ & $60-80$ & $72,97 \pm 5,76$ & $72,26 \pm 6,69$ & $73,15 \pm 5,34$ & $74,11 \pm 5,17$ & $73,74 \pm 5,15$ & $73,84 \pm 4,83$ \\
\hline Albumin & $\mathrm{g} / \mathrm{l}$ & $35-50$ & $45,29 \pm 2,92$ & $43,68 \pm 2,92$ & $45,31 \pm 2,58$ & $44,78 \pm 2,08$ & $45,01 \pm 2,63$ & $44,29 \pm 2,71$ \\
\hline Összbilirubin & $\mu \mathrm{mol} / \mathrm{l}$ & $<17$ & $14,65 \pm 8,78$ & $15,4 \pm 9,83$ & $13,82 \pm 8,13$ & $14,37 \pm 10,1$ & $13,7 \pm 8,04$ & $14,55 \pm 11,04$ \\
\hline Direkt bilirubin & $\mu \mathrm{mol} / \mathrm{l}$ & $<3,4$ & $2,65 \pm 1,53$ & $2,82 \pm 1,25$ & $2,6 \pm 1,53$ & $2,4 \pm 1,28$ & $2,55 \pm 1,38$ & $2,32 \pm 1,26$ \\
\hline Vas & $\mu \mathrm{mol} / 1$ & $12,5-32,2$ & $17,16 \pm 6,76$ & $17,68 \pm 6,44$ & $16,26 \pm 4,58$ & $15,63 \pm 4,56$ & $17,91 \pm 7,83$ & $16,89 \pm 5,74$ \\
\hline Transzferrin & $\mathrm{g} / \mathrm{l}$ & $2,0-3,6$ & $2,91 \pm 0,34$ & $2,75 \pm 0,25$ & $2,89 \pm 0,41$ & $6,48 \pm 14,78$ & $2,83 \pm 0,39$ & $2,68 \pm 0,17$ \\
\hline Réz & $\mu \mathrm{mol} / \mathrm{l}$ & $13-24$ & $17,97 \pm 11,22$ & $14,64 \pm 1,97$ & $13,6 \pm 2,94$ & $21,94 \pm 27,97$ & $13,98 \pm 2,6$ & $14,04 \pm 3,16$ \\
\hline Cink & $\mu \mathrm{mol} / \mathrm{l}$ & $7,2-16,6$ & $12,72 \pm 1,54$ & $11,98 \pm 3,97$ & $11,8 \pm 1,63$ & $12,21 \pm 1,24$ & $12,36 \pm 1,78$ & $12,26 \pm 1,13$ \\
\hline $\begin{array}{l}25-\mathrm{OH}-\mathrm{D}_{3}^{-} \\
\text {vitamin }\end{array}$ & $\mathrm{ng} / \mathrm{ml}$ & $23-60$ & $20,25 \pm 4,5$ & $25,17 \pm 7,53$ & $25,75 \pm 4,52^{*}$ & $26,67 \pm 9,86^{*}$ & $20,92 \pm 4,68^{*}$ & $23,18667^{*}$ \\
\hline
\end{tabular}

25-OH-D 3 = D-vitamin-szint; ALP = alkalikus foszfatáz; GGT = gamma-glutamil-transzferáz; GOT = glutamát-oxálacetát-transzferáz; GPT = glutamát-piruvát-transzamináz; INR = nemzetközi normalizált arány; HDL = magas denzitású lipoprotein; LDL = alacsony denzitású lipoprotein 


\section{Eredmények}

A 8 hetes joghurtfogyasztás után a D-vitamin-szint kismértékű $(20,25$-ről 25,74 ng/ml-re) növekedését találtuk ( $p=0,03)$; statisztikailag nem volt különbség a többi 35 rutin laboratóriumi adat összehasonlításakor. A májenzimszintek kedvezőtlenül mérsékelten emelkedtek (GOT: 33,29-39,44 U/1, $p=0,71$; GPT: 47,72-57,44 $\mathrm{U} / 1, p=0,15$; GGT: 101,91-126,58 U/1, $p=0,83$; ALP: 101,51-110,75 U/1, $p=0,65)$, majd a joghurtfogyasztás után 12 héttel a kezdeti állapotra csökkentek. Ez a tendencia mind a bio-, mind a hagyományos joghurtot fogyasztó csoportban megfigyelhető volt. A bilirubin- és az összkoleszterinszint lényegében nem változott, azonban a LDL-szint (64,47\%-ról 63,64\%-ra, $p=0,08)$ és a trigliceridek $(1,85-1,78 \mathrm{mmol} / 1, p=0,11)$ mérsékelt csökkenését tapasztaltuk a 8 hetes kezelés befejezését követően. Ezek a paraméterek a két csoportban hasonlóan változtak. A vas $(17,8-15,98 \mu \mathrm{mol} / 1, p=0,23)$ és a cink $(12,42-11,98 \mu \mathrm{mol} / 1, p=0,32)$ szintje minimálisan csökkent, a réz enyhén emelkedett közvetlenül joghurtfogyasztás után $(16,52-17,31 \mu \mathrm{mol} / 1, p=0,09)$. A biocsoportban a cinkcsökkenés kifejezettebb volt a hagyo-

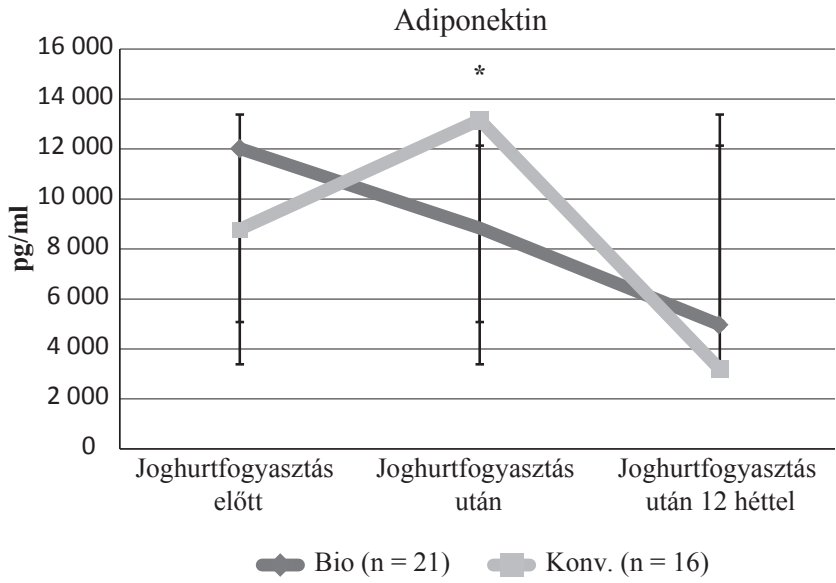

2. ábra $\quad$ Az adiponektinszint változása $\left({ }^{*}\right.$ szignifikancia $\left.\mathrm{p}<0,05\right)$

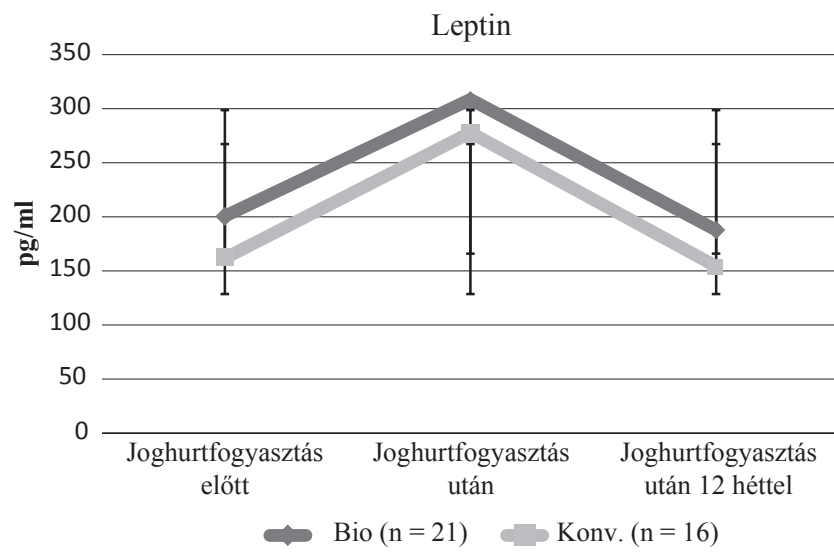

3. ábra $\quad$ A leptinszint változása $($ szignifikancia $\mathrm{p}<0,05)$

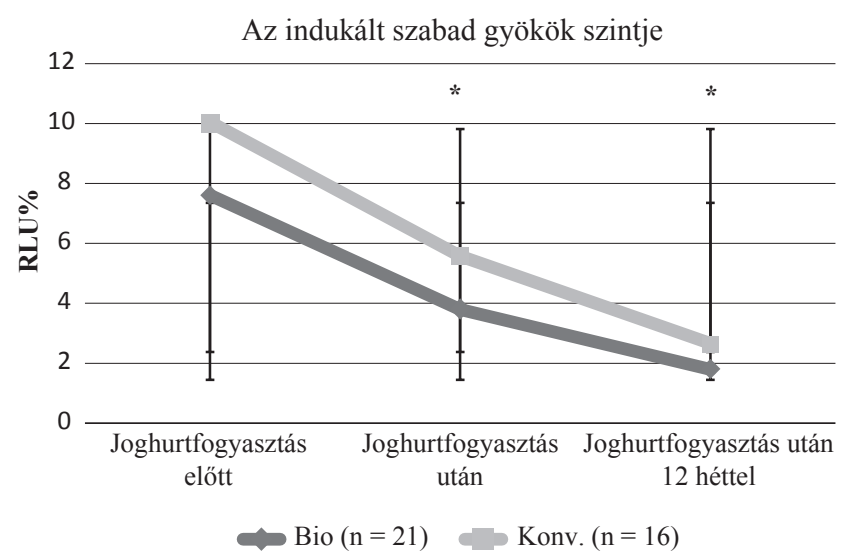

4. ábra $\quad$ Az indukált szabadgyök-szint változása (

mányos joghurtfogyasztókkal összehasonlítva, míg a konvencionális csoportban a rézszint emelkedése volt markánsabb. Ezek az eltérések azonban statisztikailag nem voltak szignifikánsak. A laboratóriumi paraméterek változását a 3. táblázat foglalja össze.

A vizsgált speciális markerek közül a citokinszintek változása emelendő ki. A két csoportban fóként az adiponektin tendenciája különbözött. Az adiponektin és a leptin szintje megnövekedett közvetlenül a joghurt fogyasztása után a „hagyományos csoportban” ( $\mathrm{n}=16$ fö). Ezzel szemben a 8 hetes kezelés után az „ökológiai csoportban” (n = 21 fó) az adiponektinszint szignifikáns csökkenését (12 017,57-ről 8833,5 pg/ml-re, $p=0,03$ ) tapasztaltuk (2. és 3. ábra).

A TNF $\alpha-(52,06 \pm 49,78-61,93 \pm 58,67 \mathrm{pg} / \mathrm{ml}, p=$ 0,54) és az IL6- $(37,42 \pm 35,89-19,48 \pm 18,11 \mathrm{pg} / \mathrm{ml}$, $p=0,67)$ szintek nem változtak szignifikánsan a kezelés hatására, illetve a mért értékek nagy szórást mutattak.

A vizsgált, redox-homeosztázist jellemző markerek közül az indukált szabad gyökök szintje statisztikailag alacsonyabb volt $(p=0,02)$ közvetlenül a joghurt fogyasztása után a „hagyományos” ( $\mathrm{n}=16$ fö) és a biocsoportban egyaránt $(\mathrm{n}=21$ fó) (4. ábra), majd tovább csökkent a 12 hetes utánkövetéskor $(p=0,01)$. Az antioxidáns védekezőképességet jelző szabadszulfhidril-tartalom $(0,38-0,4 \mathrm{mmol} / \mathrm{l})$ és hidrogéndonáló képesség (27,5-28,04 gátlás\%) minimálisan változott a kezdeti állapothoz képest.

A testösszetételben nem találtunk szignifikáns különbségeket a kezelés után (4. táblázat). A két csoportban lényegi különbség nem mutatkozott. Ugyanakkor kiemelendő, hogy a biocsoportban 10 betegnél, a hagyományos csoportban 12 betegnél mértünk enyhe testsúlycsökkenést $(-0,54 \pm 0,32 \mathrm{~kg}, p=0,21)$ a 8 hetes joghurtfogyasztás után.

\section{Megbeszélés}

A probiotikus, fermentált élelmiszerek, elsősorban a tejtermékek egyre nagyobb hangsúlyt kapnak krónikus betegségek kiegészítő kezelése kapcsán a bélflóra befolyá- 
4. táblázat |A testösszetétel-mérés változása a két csoportban $(\mathrm{n}=37$ fö) (szignifikancia $\mathrm{p}<0,05)$

\begin{tabular}{lccccc}
\hline Paraméter & Mértékegység & Normáltartomány & Joghurtfogyasztás elött & Joghurtfogyasztás után & Joghurtfogyasztás után 12 héttel \\
\hline Súly & $\mathrm{kg}$ & & $89, \pm 15,5$ & $88,59 \pm 15,38$ & $88,43 \pm 15,78$ \\
\hline Magasság & $\mathrm{cm}$ & & $168, \pm 10,08$ & $168,14 \pm 10,03$ & $167,85 \pm 10,32$ \\
\hline Teljes testvíz & $\mathrm{kg}$ & $33,7-41,1$ & $42,39 \pm 8,6$ & $41,85 \pm 8,5$ & $41,43 \pm 8,81$ \\
\hline Fehérje & $\mathrm{kg}$ & $2,47-3,81$ & $3,9 \pm 0,83$ & $3,82 \pm 0,8$ & $11,08 \pm 2,38$ \\
\hline Ásványi anyagok & $\mathrm{kg}$ & $7,2-16,8$ & $31,47 \pm 11,52$ & $31,72 \pm 11,32$ & $3,77 \pm 0,84$ \\
\hline Testzsírtömeg & $\mathrm{kg}$ & $25-30$ & $32,27 \pm 7,11$ & $31,81 \pm 6,93$ & $31,44 \pm 7,23$ \\
\hline Vázizomtömeg & $\mathrm{kg} / \mathrm{m}^{2}$ & $20-25$ & $31,61 \pm 5,4$ & $31,46 \pm 5,31$ & $31,49 \pm 5,55$ \\
\hline BMI & $\%$ & $18-30$ & $34,91 \pm 10,05$ & $35,38 \pm 9,73$ & $35,93 \pm 10,14$ \\
\hline Testzsírszázalék & $\mathrm{cm}{ }^{2}$ & 100 & $147,47 \pm 56,99$ & $150,47 \pm 57,2$ & $154,69 \pm 59,84$ \\
\hline Visceralis zsír területe & $\mathrm{kcal}$ & & $1615,48 \pm 254,66$ & $1598,72 \pm 250,05$ & $1585,91 \pm 259,57$ \\
\hline Alapanyagcsere & & $0,8-0,9$ & $0,96 \pm 0,06$ & $0,98 \pm 0,05$ & $0,99 \pm 0,06$ \\
\hline Derék-csípó arány & $\mathrm{kg}$ & $2,03-3,13$ & $3,21 \pm 0,68$ & $3,15 \pm 0,66$ & $3,1 \pm 0,69$ \\
\hline $\begin{array}{l}\text { A csontok ásványianyag- } \\
\text { tartalma }\end{array}$ & $\mathrm{kg}$ & $23,7-36,5$ & $37,63 \pm 7,83$ & $37,13 \pm 7,61$ & $36,73 \pm 7,94$ \\
\hline Testsejttömeg & & & &
\end{tabular}

solása miatt. Az egészségre gyakorolt pontos hatásuk azonban vitatott a betegkövetés nehézségei miatt. Eredményeink arra utalnak, hogy kiegészítő terápiás hatásuk kétséges a nem alkoholos zsírmájbetegség kezelése során. A tanulmányba bevonásra került betegeknél a májtranszamináz-szintek enyhe emelkedését tapasztaltuk nem szignifikáns módon, közvetlenül a 8 hetes joghurtfogyasztás után, ami kedvezőtlen [17], ezt azonban elsősorban a betegség természetes lefolyásából adódó dinamikus változásnak tudtuk be. A máj szintetikus funkcióját jelző bilirubin-, protrombin- és albuminszintek lényegében változatlanok voltak. A betegség patogenezisében fontos szerepet játszó $[18,19]$ LDL-szint minimális csökkenését tapasztaltuk mindkét csoportban a kezelés után, változatlan összkoleszterinszint mellett, ami a vérlipidprofil kedvezőbb összetételét jelentheti a betegségben.

Az általunk vizsgált speciális markerek közül az adipocitokinek tendenciózus változása emelendő ki. Számos tanulmány támasztja alá, hogy a májelzsírosodásban fontos szerepet játszik a zsírszövet [20]. A zsírszövet diszfunkcióját a megnövekedett leptinszint és a csökkent adiponektinszint jelzi [21]. Tanulmányunkban a joghurtfogyasztás után észlelt leptinszint-emelkedés kedvezőtlen mindkét csoportban, míg a konvencionális csoportban tapasztalt adiponektinszint-emelkedés előnyös lehet $[21,22]$. A vizsgálatban alkalmazott joghurtok eltérő zsírsavösszetétele (többszörösen telítetlen zsírsav tartalom: hagyományos joghurtban $0,16 \mathrm{~g} / 100 \mathrm{~g}$; biojoghurtban 0,15 g/100 g) befolyásolhatta a zsírszövet adipocitokintermelését [23]. Az adiponektinről ismert, hogy elősegíti a vázizom glükózfelvételét és zsírsav-oxidációját, valamint gátolja a glükoneogenezist, a lipogenezist és a máj elzsírosodását [24]. A magasabb szérumleptinszintek ezzel szemben kockázati tényezői lehetnek a cardiovascularis megbetegedések, valamint a leptinrezisztencia kialakulásának NAFLD-ben [25].

Kritikus szerepet játszik a NAFLD progressziójában továbbá a pro- és antiinflammatorikus ingerek közötti egyensúlyhiány. A gyulladásos sejtek toborzása és aktivációja révén oxidatív stressz jön létre, és fokozódik a lipid felhalmozódása a hepatocytákban. A steatosis zavart okoz a mitokondriális aktivitásban, valamint az antioxidáns rendszerekben is [26]. További gyulladásosaktivitás-fokozódás tapasztalható a bélflóra megváltozása során. A bakteriális endotoxinok - átjutva a bélfalon, bekerülve a portalis áramlásba - gyulladásos választ indukálnak a májban, ami további oxidatív stresszt jelent a májsejteknek. A károsodott bélfalon keresztül gyakran nehezített a táplálékból a bioaktív hatóanyag felvétele és hasznosulása. A fokozott oxidatív stressz, valamint a csökkent exogén vitamin- és ásványianyag-felvétel jelentősen terheli a szervezet, elsődlegesen a máj antioxidáns védelmi mechanizmusát $[4,27]$. Az a pre- vagy probiotikum, amely hozzájárul a bélflóra természetes harmóniájának helyreállításához, csökkentheti a termelődő reaktívoxigén-gyököket, illetve javíthatja a szervezet antioxidáns védekezőmechanizmusát. Tanulmányunk során az indukált szabad gyökök szintje statisztikailag alacsonyabb volt mindkét joghurtfogyasztás alatt és az utánkövetés időpontjában is. Emellett enyhe antioxidánskapacitás-fokozódást is tapasztaltunk a résztvevőknél. Továbbá szignifikánsan magasabb D-vitamin-szintet mértünk a joghurtfogyasztás után, amely szintén kedvezően hathat a betegség lefolyása szempontjából. A Dvitamin-hiány ugyanis összefüggést mutat a gyulladásos folyamatok, az elhízás, az inzulinrezisztencia, a diabetes mellitus, a hypertonia, a hyperlipidaemia és a perifériás érbetegség kialakulásával [28]. 
A NAFLD a metabolikus szindróma része, amely magában foglalja a centrális hasi elhízást és a testösszetétel eltéréseit. A zsírszövet eloszlása nagyobb szerepet játszik az inzulinrezisztencia kialakulásában a betegség során, mint a gyakran alkalmazott mutató, a testtömegindex [29]. Munkánkban a testösszetétel-mérés során nem tapasztaltunk változást a joghurtfogyasztás hatására, amit a betegek életmódjával, táplálkozási szokásaival magyarázunk. Kiemeljük azonban a résztvevőknél mért visceralis zsírszövet relatív eloszlását, a magasabb testzsírszázalékot, testtömegindexet, derék-csípő arányt. Ezen mutatók klinikai értékelése, monitorizálása fontos a későbbi szövődmények, illetve társbetegségek kialakulása szempontjából.

\section{Következtetés}

Világszerte emelkedik a metabolikus szindróma előfordulása, ezzel párhuzamosan a nem alkoholos zsírmájbetegség (NAFLD) prevalenciája is nő. A NAFLD a krónikus májbetegségek egyik leggyakoribb oka a nyugati országokban, amely az előrejelzések szerint 2030-ra a májátültetések leggyakoribb indikációja lesz [30]. A NAFLD terápiája jelenleg nincs megoldva. Kezelése elsősorban az életmód komplex megváltoztatásán (étrendmódosítás, a bevitt energia csökkentése, a testmozgás növelése) alapszik. Ezen tényezők hathatnak a bélflóra összetételére, metabolikus aktivitására is [9]. Munkánk során az intenzív bélflóra-módosító kezelés rövid távú hatását vizsgáltuk, a klinikai paraméterekben azonban minimális változást tapasztaltunk. Ennek hátterében elsősorban a rövid kezelési időtartam, a nem kellően homogén betegcsoport, valamint az alacsony esetszám állhatott. Kiemelendő továbbá, hogy a kereskedelmi forgalomban kapható élelmiszerek fogyasztásától nagymértékü klinikai változás nem várható el rövid távon.

Másik fontos kérdésfelvetésünk a tanulmány során, hogy az ökológiai gazdálkodásból származó joghurtok fogyasztása kedvezőbb-e a hagyományosan előállított tejtermékekhez képest, nem igazolódott. Bár nem volt klinikailag szignifikáns különbség az ökológiai és a hagyományos joghurt fogyasztása között, eredményeink arra utalhatnak, hogy az adiponektin megfelelö biomarker lehet a NAFLD probiotikus kezelésének követésére. A bélflóra egyensúlyának helyreállítása összességében kedvezően hathat a betegség lefolyása, valamint további társbetegségek, szövődmények kialakulásának megelőzése szempontjából. Munkánk alapul szolgálhat a jövőbeli tanulmányokhoz, amelyek tisztázzák a probiotikus termékek fogyasztása és az egészségi hatások közötti kapcsolatot.

Anyagi támogatás: A kutatásokat a Semmelweis Egyetem 2/1 PhD-Iskola támogatta.
Szerzői munkamegosztás: E. A.: A téma felvetése, irodalomkutatás, speciális markerek meghatározása, a shear wave elasztográfiás mérések elvégzése, adatelemzés, a közlemény megírása. D. D.: A joghurtok beszerzésének koordinálása. H. K., L. G.: A betegek bevonása és kezelése, a diagnózis felállítása, a kutatás irányítása. J. Zs.: A shear wave elasztográfiás mérések felügyelete. Bl. A.: A speciális markerek meghatározásának felügyelete. K. I.: A rutin laboratóriumi paraméterek meghatározása. D. S.: A testösszetétel-mérések elvégzése. Ba. A.: Adatelemzés, részvétel a speciális markerek meghatározásában. A cikk végleges változatát valamennyi szerző elolvasta és jóváhagyta.

Érdekeltségek: A szerzőknek nincsenek érdekeltségeik.

\section{Köszönetnyilvánítás}

Köszönjük az Ökológiai Mezőgazdasági Kutatóintézetnek, a SoleMizo Zrt.-nek és a Kärntnermilch GmbH-nak, hogy a vizsgált joghurtokat rendelkezésünkre bocsátották.

\section{Irodalom}

[1] Maffeis C, Morandi A. Body composition and insulin resistance in children. Eur J Clin Nutr. 2018; 72: 1239-1245.

[2] Boursier J, Diehl AM. Nonalcoholic fatty liver disease and the gut microbiome. Clin Liver Dis. 2016; 20: 263-275.

[3] Haque TR, Barritt AS 4th. Intestinal microbiota in liver disease. Best Pract Res Clin Gastroenterol. 2016; 30: 133-142.

[4] Brandl K, Kumar V, Eckmann L. Gut-liver axis at the frontier of host-microbial interactions. Am J Physiol Gastrointest Liver Physiol. 2017; 312: G413-G419.

[5] Bertók L. Bile acids and endotoxins: physico-chemical defense of the body. [Epesavak és endotoxinok: a test fiziko-kémiai védelme.] Orv Hetil. 1999; 140: 3-8. [Hungarian]

[6] Kundu S, Kumar S, Bajaj A. Cross-talk between bile acids and gastrointestinal tract for progression and development of cancer and its therapeutic implications. IUBMB life 2015; 67: 514523.

[7] Şanlier N, Gökcen BB, Sezgin AC. Health benefits of fermented foods. Crit Rev Food Sci Nutr. 2019; 59: 506-527.

[8] Paolella G, Mandato C, Pierri L, et al. Gut-liver axis and probiotics: their role in non-alcoholic fatty liver disease. World J Gastroenterol. 2014; 20: 15518-15531.

[9] Sáez-Lara MJ, Robles-Sanchez C, Ruiz-Ojeda FJ, et al. Effects of probiotics and synbiotics on obesity, insulin resistance syndrome, type 2 diabetes and non-alcoholic fatty liver disease: a review of human clinical trials. Int J Mol Sci. 2016; 17: 928.

[10] Tunick MH, Van Hekken DL. Dairy products and health: recent insights. J Agric Food Chem. 2015; 63: 9381-9388.

[11] Walther B, Wechsler D, Schlegel P, et al. Iodine in Swiss milk depending on production (conventional versus organic) and on processing (raw versus UHT) and the contribution of milk to the human iodine supply. J Trace Elem Med Biol. 2018; 46: 138143.

[12] Unger AL, Bourne DE, Walsh H, et al. Fatty acid content of retail cow's milk in the Northeastern United States - what's in it for the consumer? J Agric Food Chem. 2020; 68: 4268-4276.

[13] Welsh JA, Braun H, Brown N, et al. Production-related contaminants (pesticides, antibiotics and hormones) in organic and conventionally produced milk samples sold in the USA. Public Health Nutr. 2019; 22: 2972-2980. 
[14] Blázovics A, Sárdi É. Methodological repertoire development to study the effect of dietary supplementation in cancer therapy. Microchem J. 2018; 136: 121-127.

[15] Hatano T, Kagawa H, Yasuhara T, et al. Two new flavonoids and other constituents in licorice root: their relative astringency and radical scavenging effects. Chem Pharm Bull (Tokyo). 1988; 36: 2090-2097.

[16] Ellman GL, Lysko H. Disulfide and sulfhydryl compounds in TCA extracts of human blood and plasma. J Lab Clin Med. 1967; 70: 518-527.

[17] Gusdon AM, Song KX, Qu S. Nonalcoholic fatty liver disease: pathogenesis and therapeutics from a mitochondria-centric perspective. Oxid Med Cell Longev. 2014; 2014: 637027.

[18] Nakamura MT, Yudell BE, Loor JJ. Regulation of energy metabolism by long-chain fatty acids. Prog Lipid Res. 2014; 53: 124-144.

[19] Persico M, Iolascon A. Steatosis as a co-factor in chronic liver diseases. World J Gastroenterol. 2010; 16: 1171-1176.

[20] Nier A, Huber Y, Labenz C, et al. Adipokines and endotoxemia correlate with hepatic steatosis in non-alcoholic fatty liver disease (NAFLD). Nutrients 2020; 12: 699

[21] Saxena NK, Anania FA. Adipocytokines and hepatic fibrosis. Trends Endocrin Metabol. 2015; 26: 153-161.

[22] Angin Y, Arslan N, Kuralay F. Leptin-to-adiponectin ratio in obese adolescents with nonalcoholic fatty liver disease. Turk J Ped. 2014; 56: 259-266.

[23] Martins SV, Lopes PA, Alfaia CM, et al. Serum adipokine profile and fatty acid composition of adipose tissues are affected by conjugated linoleic acid and saturated fat diets in obese Zucker rats. Br J Nutr. 2010; 103: 869-878.
[24] Salman AA, Sultan AA. Effect of weight loss induced by laparoscopic sleeve gastrectomy on liver histology and serum adipokine levels. J Gastroenterol Hepatol. 2020 Mar 9. Doi: 10.1111/ jgh.15029. [Online ahead of print]

[25] Brennan AM, Mantzoros CS. Drug Insight: the role of leptin in human physiology and pathophysiology - emerging clinical applications. Nat Clin Pract Endocrinol Metab. 2006; 2: 318-327.

[26] Świderska M, Maciejczyk M, Zalewska A, et al. Oxidative stress biomarkers in the serum and plasma of patients with non-alcoholic fatty liver disease (NAFLD). Can plasma AGE be a marker of NAFLD? Oxidative stress biomarkers in NAFLD patients. Free Radic Res. 2019; 53: 841-850.

[27] Abdul-Hai A, Abdallah A, Malnick SD. Influence of gut bacteria on development and progression of non-alcoholic fatty liver disease. World J Hepatol. 2015; 7: 1679-1684.

[28] Cho YH, Kim JW, Shim JO, et al. Association between vitamin D deficiency and suspected nonalcoholic fatty liver disease in an adolescent population. Pediatr Gastroenterol Hepatol Nutr. 2019; 22: 233-241.

[29] Milić S, Lulić D, Štimac D. Non-alcoholic fatty liver disease and obesity: biochemical, metabolic and clinical presentations. World J Gastroenterol. 2014; 20: 9330-9337.

[30] Byrne CD, Targher G. NAFLD: a multisystem disease. J Hepatol. 2015; 62(1 Suppl): S47-S64.

(Egresi Anna dr., Budapest, Szentkirályi u. 46., 1088 e-mail: egresi.anna@gmail.com)

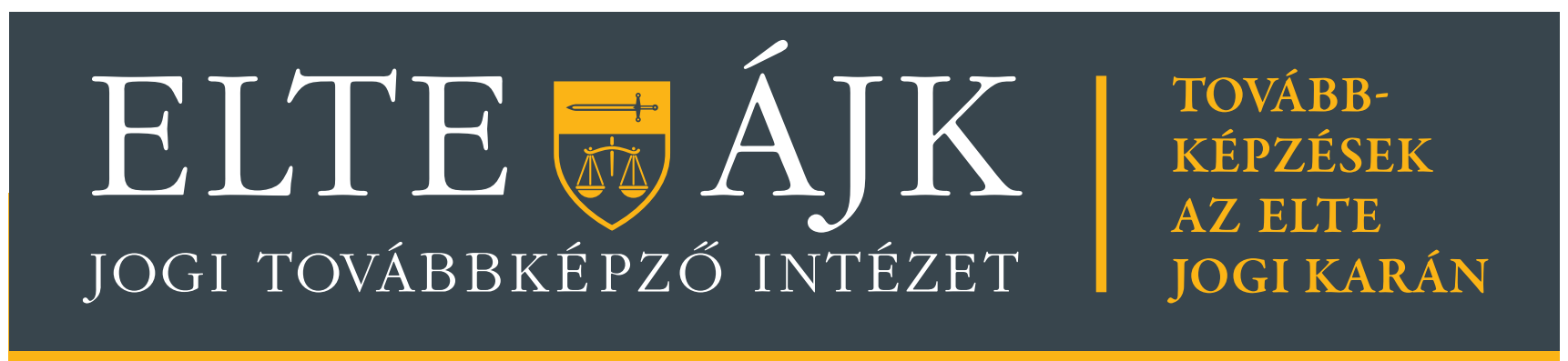

\section{Helyszín:}

ELTE Föépület,

1053 Budapest,

Egyetem tér 1-3.

(1)

További információk:

https://jotoki.elte.hu/

\section{Egészségügyiszakjogász képzés}

- átfogó elméleti és gyakorlati jogi tudást biztosít az egészségügy területén

- hatékony segítség az egészségügyi intézményműködtetés átlátásában, az egészségpolitikai döntéshozatal, az állami és a magán-egészségbiztosítás, egészségügyi ellátás jogalkotás komplex működési folyamatainak megértésében

- célcsoportja: egészségügyi joggal foglalkozó bírók, hatósági tisztviselők, ügyvédek, egészségügyi intézményi jogtanácsosok, gyógyszerforgalmazó cégek, egészségügyi beszállítók

\section{Jogi szakokleveles orvos- és egészségügyi szakember képzés}

- hatékony jogi, igazgatási problémakezelés az egészségügy működése és működtetése során - a képzés fontos feladata, hogy kialakítsa a betegellátással kapcsolatos konfliktushelyzetek felismerésének és megfelelö kezelésének, a betegjogok gyakorlati érvényre juttatásának képességét - célcsoportja: orvosok, fogorvosok, gyógyszerészek

\section{További képzéseink az egészségügyben dolgozók számára:}

• Adatbiztonsági és adatvédelmi szakjogász • Munkajogi szakjogász • Adójogi szakjogász

A cikk a Creative Commons Attribution 4.0 International License (https://creativecommons.org/licenses/by/4.0/) feltételei szerint publikált Open Access közlemény, melynek szellemében a cikk bármilyen médiumban szabadon felhasználható, megosztható és újraközölhető, feltéve, hogy az eredeti szerző és a közlés helye, illetve a CC License linkje és az esetlegesen végrehajtott módosítások feltüntetésre kerülnek. (SID_1) 